\title{
IDEAS OF JUSTICE: Relevance of Weber's Approach
}

\author{
Jan-Erik Lane
}

\begin{abstract}
A book so overall critical as The Idea of Justice by A. Sen requires a Popper inspired examination. The results are that his rejection of Rawls is flawed and that he entirely lacks meta-ethics. The continental Weberian approach to normative enquiry has been severely neglected by many scholars in the AngloSaxon tradition, trying in vain to identify the true nature of justice.
\end{abstract}

Keywords: Sen, Barry, Rawls, Weber

\section{Introduction}

Justice, both the word and the conceptions, figure prominently in political science, in both the micro and the macro contexts. And in political history, ideas of justice have been central from the pre-socratics to the emergence of environmentalism and cultural discourses. Of course, other social sciences and philosophy share this interest in questions about what is just with political sciences, as the concepts of justice can be examined from several angles: domestic politics or economics, international economics or politics, gender, culture, inter generations, etc. Here, I focus only upon the general analyses of justice with a few Anglo-Saxon authors, namely Rawls, Barry and Sen. I wish to show the relevance of distinguishing between criteria of justice and the theory that argues in favour of just criteria.

Many other scholars could be drawn into this critical enterprise, but I wish to argue that the approaches of Rawls, Barry and Sen, whatever their major differences, contrast very much with an entirely different approach to justice and moral theories, namely that of Max Weber (1922), emphasizing conflict like Nietzsche when different ideas of justice clash in politics. The Weberian approach has been completely bypassed in modern justice discourse in Anglo-Saxon culture, despite the fact that it has many adherents, receiving alternative formulations with major authors like Kelsen, Haegerstroem, Kaila, Brecht, Foucault, A. Ross, the logical positivists, etc.

Perhaps there is some crucial insight in the position that principles of justice will ultimately depend upon the acceptance of evaluations, i.e. moral evaluations. Actually, prominent Anglo-Saxon authors like e.g. Hume and Ayer have argument similarly.

\section{THEORIES OF JUSTICE AND "JUSTICE"}

Scholars who argue that just principles is merely a set of contradictory ideas about justice, reflecting the interests of the scholar or his community, often rely upon the semantic approach to moral terms or words. Weber did not, but for others the non-cognitivist approach to moral words offered a decisive rebuttal of all attempts to arrive at one and only one Platonian idea of justice. In meta-ethics, it was claimed that sentences like " $\mathrm{X}$ is just" or " $\mathrm{X}$ fulfils justice" were moral propositions with strong emotive content or with normative recommendation. Thus, "justice" is a value biased conception or a propaganda device for influencing people. However, meta-ethics cannot decide moral questions. If words like "just" or "justice" is value-loaded conceptions - see Myrdal (1958), then why not use others words like "fair" or "fairness" and "equitable", etc.?

A lasting achievement in modern meta-ethics is the sharp separation between IS and OUGHT, which recurs not only in Hume but also with Weber. Thus, validating the following two sentences e.g.:

(1) Kashmir is part of Indian state;

(2) Kashmir should be decided by a popular referendum,

Call up...the distinction between verification: truth and false against moral justification: just or unjust. The Is and Ought separation is crucial in theories of justice, hardly overcome in American pragmatism.

Finally, a few words on the method of argument below, starting from the Oxford Dictionary entry to "just" as: "Based on or behaving according to what is 
morally right and fair". The Oxford Thesaurus gives the following synonyms for "social justice":

fairness, justness, fair play, fair-mindedness, equity, equitableness, even-handedness, egalitarianism, impartiality, impartialness, lack of bias, objectivity, neutrality, disinterestedness, lack of prejudice, openmindedness, non-partisanship.

One notes especially the many synonyms that carry a risk for circular definitions like "justice" = impartiality," and "impartiality" = "justice". One also sees the need for criteria of justice, which give practical information about how to evaluate the extent of justice and propose concrete policies improving justice. The set of criteria has to be motivated by a theoretical argument about the place of justice in political and normative economic theory.

Perhaps one should point out that social justice and legal justice only partially overlap conceptually. In one Dictionary we have this entry for "justice":

a: the quality of being just, impartial, or fair questioned the justice of the their decisions (1) : the principle or ideal of just dealing or right action (2): conformity to this principle or ideal: righteousness the justice of their causes: the quality of conforming to law.

Yet, social justice theories are not restricted to the law, but offers criteria to evaluate a just law or legal order.

\section{RAWLS}

The magnum opus of Rawls, A Theory of Justice (2005), was published exactly when the emotive or prescriptive theories of "justice" had run their course as interesting projects in early 1970s. Scholars were not convinced by Kelsen saying that justice could be defined arbitrarily, or Haegerstroem claiming that "justice" simple meant "Oh so good", nor by Ross stating that "justice" lacked meaning entirely. It seemed that utilitarianism despite many developments was not an entirely convincing macro approach.

The dominance of logical positivist's framework for ethical discourse was replaced by innovations of the natural law approach, focusing upon cognitivist metaethics, deontological ethics and a micro focus upon the rights of individuals - see e.g. Nozick, 2001 and Dworkin, 2000). Rawls offered the most original ethical theory and perhaps also the most systematic, comprising both the set of justice criteria and an elaborate theory to derive these rights.

Rawls developed his theory of justice, integrating various other concepts in consecutive books and articles. Here, there is only space for considering his criteria of justice and its theoretical motivation. Firstly, we have the criteria:

"First Principle: Each person has the same indefeasible claim to a fully adequate scheme of equal basic liberties, which scheme is compatible with the same scheme of liberties for all;

Second Principle: Social and economic inequalities are to satisfy two conditions:

a. They are to be attached to offices and positions open to all under conditions of fair equality of opportunity;

b. They are to be to the greatest benefit of the least-advantaged members of society (the difference principle). (JF, 42-43)"

I will call the first principle "liberty under the rule of law" and the second one "equality under maximin". Both sets of criteria need no explication but can be applied both to political regimes and in public policies. The maximin principle was radical at the time when liberalism or public choice dominated. It separated Rawls from Hayek and Nozick for instance, but more radical interpretations of equality would surface with Dworkin and especially Barry. Both sets of justice criteria with Rawls are of course operational.

Rawls justice criteria called for both liberty and equality - thus "liberal egalitarianism". They were revolutionary for the political theory in the US but hardly much different than Social Democracy ideals in Europe. The originality with Rawls came with the argument for these two principles, namely choosing justice under a veil of ignorance. The idea of a veil of ignorance is meant to meet the often made requirement that justice criteria are impartial, i.e. do not merely rationalize the person position of the chooser, endorsing the status quo if in a favourable position and calling changes in a negative position. In a veil of ignorance, the choosing person knows 
nothing, not even his/her personal characteristics - a remarkably strange construction.

However, the is abstruse construction can be turned into a game of incomplete information where Nature makes the first move, putting a real person into a positive or negative position with regard to life opportunities. Fearing the negative position, a rational choice is to bet upon risk aversion, meaning choosing justice principles that institutionalise liberty under rule of law firstly and secondly equality under economic efficiency. Now, things make sense, as these choices are Nash equilibria.

Now, the only objection that may be raised within this deontological framework is to question risk aversion. Maybe the person could be risk prone? Then Rawls' theory collapses. In the Weberian approach, these two choices will be made on the basic of values, or subjective evaluations morally.

\section{BARRY}

Late Brian Barry published much in ethics though never in meta-ethics. The bulk of his ideas on justice are contained in three major books, one evaluating theories, one stating his own contribution in deontolo gical ethics, and a final volume applying his abstract theory of justice as impartiality to practical criteria allowing for the making of public policy.

Barry's theory of justice implies that the legal criterion of justice as impartial treatment in the court and under the law is to be radically extended to all spheres of state and society, to be applied in all public policies in the form of justice criteria that substantiate the notion of impartiality as far as possible, also in the market and the determination of income and wealth.

I will not deal much with his Why Social Justice Matters (2005), where he comes up with a whole set of policies of social justice. It is basically all about achieving equality, not of opportunity but of outcomes. I think many of these justice criteria can be dismissed, like for instance the total rejection of merit or deservedness. Some car hardly be "taken seriously," as Barry himself often called some of his opponents like Lijphart and Sartori. Other justice criteria fail the maximin, as they could worsen the groups Barry want to be treated impartially, namely the lower echelons in society and markets. The interesting originality with Barry is not his brand of socialism but his theory arguing for the idea of justice as impartiality. Why advocate socialism when it has failed at some many places, recently in Venezuela? The Swedish Social Democratic welfare state no longer is in existence, as the so-called "people's home" has been replaced by a welfare society, based on the maximisation of personal greed.

Now, what could be the rationale of extending the principle of impartiality from the legal order to the moral order? In the Weberian framework, such a theory would have to show that positive outcomes outweigh negative ones. At the end of this evaluation, there would be a choice of moral values: equality of opportunity against equality of results. Yet, Barry rejects both utilitarianism and ultimate values as grounds for justice, arguing in his theory based on reason alone for the thesis that impartiality amounts to "what no one can reasonable deny or reject" - the socalled Scanlon criterion.

And why could not people with higher income or more wealth reject a demand for strict equality? They can of course for egoistic reason, but not from the stand-point of the justice criterion. Is then equality of outcomes an implication from the concept of reasonableness? Weber would deny that, perhaps referring to Hume, the greatest philosopher of ethics in Great Britain. Barry's argument goes like this, formally speaking:

1) Justice = Impartiality

2) Impartiality = Equality

3) Equality = Equal results

4) Justice = equality of outcomes

The error lies in the $3^{\text {rd }}$ assumption.

When Swedish state and society has been changed by a Bourgeoisie government from a welfare state to a welfare society, undoing the mixed economy of the Arbeiterbewegung, is that "unreasonable" policymaking? Or is the transition a matter of a different approach to justice, i.e. other ultimate values, favouring merit, deservedness, inheritance, economic freedom, markets - capitalism?

One may feel sympathy with Barry's frustration concerning the global rising inequalities. Together with climate change, they make for profoundly great 
challenges to the civilisations and mankind in this century.

\section{SEN}

Amitai Sen dealt with moral theory in the first half of his life, examine utilitarianism and social choice inter alia. He has in the latter half of his life turned much to moralism inter alia. Thus, he defends oriental despotism and comprehensively magic Hinduism in one book, knowing of course that rule of law was brought to India and the Nehru family by the British. Moreover, he says in another book that socioeconomic development is freedom, but what he really wants to argue is that development should be freedom enhancing - the Hume confusion. Political freedom in China has not augmented with its phenomenal economic development. And the fate of Hong Kong with its strong academic liberties is most probably grim.

The Idea of Justice (2009) comprises a tour de force rejection of Rawls' theory, whether his criteria or his derivation from the original position. In contains many errors, like the following for instance:

(1) RT is transcendental, no. On the contrary, Rawls' criteria are very mundane and would carry enormous change if implemented around the world. Rawls' derivation comprises the strange image of choosing principles of justice under a veil ignorance about who the person. It is an unnecessary theoretical abstraction that can be replaced by a simple game of incomplete information.

(2) RT is based upon a priori assumptions, yes, but all theories of justice are so. One cannot observe justice in reality, as it is in the eyes of the beholder. Man is the measure of all, said Greek philosopher Protagoras (in ethics, I would add). Some criteria of justice have to be introduced before one can evaluate the reality. And they need theoretical justification. To Weber, these must be ultimate values like liberty and equality.

(3) RT is impractical, not at all. The two principles of justice - freedom under rule of law and equality under efficiency - can be directly translated into practical policymaking. Thus, authoritarian countries should adopt freedom under rule of law and capitalist democracies equality under efficiency. Huge changes are certainly feasible!

RT is redundant, wrong again. One may suggest other principles of justice, if one can motivate them. Bur any justice evaluation of reality requires some principles or criteria. RT is easily applied in rule of law indices as well as in GINI-indices.

RT presumes total ordering, not correct. One may employ Rawls' criteria to document basic differences among Asian countries in terms of freedom under rule of law. Similarly, one may enquire into weather the US is scoring higher or lower on equality under efficiency over a long time period. No need to deal with all countries on the globe.

RT can only give strict orders, incorrect. Several countries score about the same on the WB rule of law index, corresponding to the first criteria. And countries may be about the same distance from the maximin.

Weak and partial justice orders are enough, no. One would always want to know what justice criterion (criteria) has generated the ordering and whether alternatives - feasible or ideal - have been left out.

RT admits no utilitarian criteria. Correct. But it constitutes no objections as long as the inherent difficulties with utilitarianism remain unresolved, like for instance The Repugnant Objection.

Smith's impartial observer is the solution to justice evaluation. No. Since justice is defined as impartiality, it is merely a tautology. The impartial observer can do no wrong, because impartiality judgements are justice propositions per definition.

(10) Smith's impartial observer and Rawls' veil of ignorance flow from the same approach to justice, namely Barry's equation of justice and impartiality.

11) Who is the impartial observer? The person who is just - circular reasoning again. The person who endorses equality of opportunity or equality of outcomes? A great scientist like Keynes or Freedman? A religious guru like Buddha or 
Confucius? We need a definition of the nature of an "impartial" individual?

12) RT does not recognize non transcendental ethics like e.g. Karl Marx’ system. Right. But Rawls wants a liberal approach with equality added. Does the idea of the Dictatorship of the Proletariat really belong to liberal egalitarianism? Whenever it has been installed, it lingers on, resulting in massive wealth for the Vanguard of the Proletariat. Marx was definitely a transcendentalist, filling Dialectical Materialism with the Laws of History - see Avineri, 2008. Just reflect: If Russia had experienced a regime honouring freedom under rule of law instead of a form of Marxism, it would be as rich and happy as the US, most probably.

13) RT covers the transcendent notion of a social contract about justice, Right. But a contract could be a modern constitution as well as a referendum. Not transcendent framework at all.

Liberal egalitarians deliver alternative theories of justice, but their justice criteria all underline the relevance of equality. This is very understandable, given the mounting evidence of extreme inequality in income and wealth globally, resulting in dismal poverty, child malnourishment and premature deaths. However, the lack for liberty also needs to be emphasized, as authoritarianism is far from a regime of the past. Rule of law seems never to come to Russia for instance.

Rawls' criteria highlights these facts in a comparative moral evaluation His theory may need to be developed in various directions, like global justice, or concrete policies to enhance rule of law or move economies towards the maximin.

\section{WEBER: Ultimate Values}

In the Weberian tradition, including major theoreticians on ethics and meta-ethics in continental Europe but also to some extent in the Anglo-Saxon world, one may arrive at the same justice criteria as in liberal egalitarianism, but there be differences, other emphasis and additional criteria. However, the approach would be entirely different, underlining values and downplaying the role of reason with Rawls or what is reasonable with Barry.
The basic ideas with Weber on science and ethics were laid down in his articles on the philosophy of the social sciences, only recently translated fully into English. Starting from the omnipresence of conflicts about what is just including immense violence and warfare, Weber realistically endorsed the Humean position that:

Reason alone cannot deduce ethical proposition;

$>$ Reason may play a tremendously important role in analysing ethical alternative and their consequences.

> Ultimately, ethical choices will be based upon moral evaluations, from either the point of view principles or consequences.

$>$ Ultimate moral evaluations are neither true nor false. They are accepted or rejected by emotion or will, not reason.

$>$ Ethical decision tend to be complex, involving both facts and values.

$>$ People tend to have different values, which is due to both interests and principles.

$>$ People's values depend upon several factors, of which social conventions constitute one.

> Modern society is characterized by several ultimate value conflicts, where freedom against obligation and equality of opportunity and equal results constitute two examples.

The social sciences face great tasks in analysing the value conflicts in the world of politics and economics today. If they also wish to deliver normative judgements about the just society, just policies or the just action, they have to specify the value premises from where they begin, as emphasized by economist Myrdal (1970).

\section{CONCLUSION}

Looking at ethical discourse today, one notes the confrontation between liberal egalitarianism of Rawls, Dworkin and Barry and the neo-liberalism of Nozick and Hayek It is much related to the conflict between liberty and equality, which is a tension between values, according to the continental Weberian approach. At the end of the day, it cannot be resolved merely by analysing consequences, as with utilitarianism, or deduction from reasonable principles, as with deontological framework One has to make up one's mind about one's values - the Kierkegaard insight: Either - Or. 
Sen appears to lack insight into the philosophy of meta-ethics, proceeding to introduce a partial or weak order on the justice of states of affairs without any moral criterion. This is value objectivism a la Moore! His attack on Rawls is profoundly flawed, comprising absurd accusations about transcendence, etc. Rawls is clear about the criteria of justice and he derives them a theory of ignorance, corresponding to the impartiality requirement of Smith, Barry and Sen!

Yet, Rawls' value judgements would be rejected by neo-liberals and libertarians when it comes to equality under efficiency. Liberty alone would be conducive to the maximisation of economic output (maxmax), which would help the poor infinitely more than Barry's socialism and real equality (minmin). In Asian values, discipline and obedience would trump also the first principle of Rawls, freedom under rule of law.

\section{LITERATURE}

Avineri, S. (2008) The Political and Social Thought of Karl Marx. Cambridge: Cambridge UP.

Barry, B. (1992) Theories of Justice. Berkely: University of Cal Press.

Barry, B. (1996) Justice as Impartiality. Oxford: Oxford UP.

Barry, B. (2005) Why Social Justice Matters. Cambridge: Polity Press.

Brecht, A (1967). Political Theory. Princeton: Princeton UP.

Dworkin, R. (2000) Sovereign Virtue. Cambridge, MA: Harvard UP.

Hayek, F. (2006) The Constitution of Liberty. London: Routledge. (several editions)

Kelsen, H. (2007) Pure Theory of Law. Oxford: Oxford UP.

Nozick, R. (2001) Anarchy, State and Utopia. Oxford: Wiley-Blackwell (several editions)

Myrdal, G. (1958) Value in Social Theory. London: Routledge
Rawls., J. (2005) A Theory of Justice. Cambridge, MA: Harvard University Press. (several editions sine 1971)

Ross, A. (2011) On Law and Justice. London: Lawbook Exchange.

Sen, A. (2009) The Idea of Justice. Cambridge: Harvard UP.

Weber, M. (1922) Gesammelte Aufsaetze zur Wissenschaftslehre. Tuebingen: Mohr.

Myrdal, G. (1970) Objectivity in Social Research. London: Duckworth 